\title{
The Image of Men in Advertising as Perceived by Polish Students of English Philology
}

\author{
Wizerunek mężczyzn w reklamie w opinii polskich \\ studentek/studentów filologii angielskiej \\ Katarzyna PAPAJA ${ }^{1}$ \\ University of Silesia, Institute of Linguistics \\ Artur ŚWIĄTEK² \\ Pedagogical University, Krakow
}

\begin{abstract}
Images presented in advertisements are very powerful and have huge impact on our perception of the world. The roles of women and men have changed within the last decade and therefore it is worth investigating the way they are perceived in advertising. The purpose of our study was twofold. First, we aimed to find out how Polish students from the English Department at a tertiary level institution in Poland, who are mainly females, perceive the image of a man in advertising. Our second purpose was to analyse their reception of slogans used in the advertisements. In order to find out the answers to our research questions concerning the image of males in advertising as well as language of advertising, we have decided to design a special questionnaire in which the students were asked to comment on advertisements associated with particular image concerning men. The advertisements had been chosen in relation to the categories established by Frith and Müeller (2010). While analysing the data we

1 https://orcid.org/0000-0003-2808-443X

University of Silesia, Institute of Linguistics/Uniwersytet Śląski w Katowicach, Instytut Językoznawstwa katarzyna.papaja@us.edu.pl

2 (D) https://orcid.org/0000-0001-7264-3003

Pedagogical University, Krakow / Uniwersytet Pedagogiczny w Krakowie artur.swiatek@up.krakow.pl
\end{abstract}


decided to use these categories, which are to be described in the theoretical part of the article. The obtained data has allowed us to find out what the image of a man is and what kind of language is used to make the advertisements effective.

Keywords: advertising, images, slogans, perception of advertisements

\section{Streszczenie}

Wizerunki prezentowane $\mathrm{w}$ reklamach są bardzo mocne i mają ogromny wpływ na nasze postrzeganie świata. Role kobiet i mężczyzn zmieniły się w ciągu ostatniego dziesięciolecia i dlatego warto zbadać sposób, w jaki są one postrzegane w reklamie. Cel naszego badania był dwojaki. Po pierwsze, chcieliśmy dowiedzieć się jak polscy studenci anglistyki, którymi są głównie kobiety, postrzegają wizerunek mężczyzny przedstawiany w reklamie. Naszym drugim celem była analiza postrzegania przez studentki sloganów zastosowanych w reklamach. W celu zebrania odpowiedzi na nasze pytania badawcze dotyczące wizerunku mężczyzn w reklamie, a także języka reklamy, postanowiliśmy przygotować specjalny kwestionariusz, w którym studentki były proszone o skomentowanie reklam związanych $\mathrm{z}$ danym wizerunkiem dotyczącym mężczyzn. Reklamy zostały wybrane na podstawie kategorii ustalonych przez Frith i Müeller (2010). Podczas analizy danych postanowiliśmy wykorzystać te kategorie, które opiszemy w części teoretycznej naszego artykułu. Uzyskane dane pozwoliły nam dowiedzieć się jaki jest wizerunek mężczyzn w reklamie oraz jaki rodzaj języka sprawia, że reklamy są skuteczne.

Słowa kluczowe: reklama, wizerunek, slogany, postrzeganie reklam

\section{Introduction}

Nowadays, more than ever the image of a man as well as his role in society has changed from a cowboy and a construction worker in the past to a muscle man, a sophisticate in a tuxedo and a successful businessman in the present. What is even more striking is that the current image has undergone a more profound transformation into a man being depicted in a family, a man with children, or a man illustrated in partnership with women or other men. When analysing various types of advertisements, it is very important to look at slogans, which are brief, precise verbal messages directed to particular recipients, wishing to cause desirable emotions in its audience (Benedikt, 2005).

\section{The role of images and slogans in advertising}

According to Kevin Lane Keller (1993, p. 3) "an image is a perception about a brand as reflected by the brand associations held in consumer's memory". The main purpose of using images in advertising is to make advertisements more attractive and to increase the consumer awareness. Among many techniques such as music, written or spoken slogans, image is the one that has 
the greatest power of persuasion. Nowadays, nearly all mass media apart from the radio use images in which people play a crucial role. Consumers very often buy particular products because they want to identify with these people/ characters. Therefore, many advertisers tend to use famous people who are popular in the society. Paul Messaris (1997, p. 7) outlines a few roles that visual images play in advertisements:

- they can elicit emotions by stimulating the appearance of a real person or object;

- they can serve as photographic proof that something really happened;

- they can establish an implicit link between the thing that is being sold and some other images.

According to John Caples and Fred Hahn (2000, p. 223), "many advertisers use human faces in advertisements in order to grab a potential buyer's attention". What is more, a person who advertises a particular product will always look straight ahead as this is very economical (taking less space), more visible and effective. Since women are perceived as major consumers, advertising manipulates the female image in order to persuade women to buy products (Danciu, 2014).

Apart from images, slogans are considered to be extremely important because they make it much easier to increase consumers' retention rate and desire. A slogan is "a brief, concrete verbal communication directed to an anonymous recipient, wishing to cause desirable emotions in its audience" (Benedikt, 2005, p. 114). An effective slogan should be easy to remember, should arouse curiosity and imagination and what is more, it should be catchy, original, simple and linguistically attractive. From the linguistic point of view, effective slogans should consist of (ibidem):

- short sentences with short, familiar words,

- positive forms or strong negatives (e.g. never, avoid, stop),

- contracted forms as in spoken language,

- the active voice,

- the present tense,

- only necessary words to communicate the message,

- message directed to the consumer personally.

The language of advertising is characterised by its innovative use of lexical items (words) and their creation. New lexical items which are invented every day are called coinages. According to George Yule (2006, p. 53), 
"typical examples of this process are trade names for commercial products that became general terms; such as aspirin, zipper, nylon, Xerox, Kleenex or Teflon". As David Crystal (2001, p. 132) observes, "these lexical items might be just temporary attempts to fill a lexical gap or, eventually, become candidates for inclusion in all the major dictionaries - neologisms". If the customers remember the invented words, which are often used in slogans, it means that the slogan served its function and reinforced the company's image.

\section{The image of men in advertising}

There exists an extensive and increasing literature on sex stereotyping and gender role portrayal in advertising (Kay \& Furnham, 2013; Knoll, Eisend, \& Steinhagen, 2011; Verhellen, Dens, \& de Pelsmacker, 2016). Nowadays, there are over 50 studies that have examined gender portrayal in national television advertising in many different countries (Furnham, \& Mak, 1999; Furnham, \& Paltzer, 2010). In addition, a recent review considered gender-role advertising in international advertising (Shaw, Eisend, \& Tan, 2014).

Advertising has been a prime target of attack and scrutiny. The basic explanation for the critical focus on sex-role portrayal in advertising lies in the close relationship, which exists between advertising and the consumer goods industry. Advertising effectiveness largely depends on the manipulation of the consumer's self-image. Since women are perceived as the major consumers, advertising manipulates the female image in order to persuade women to buy goods According to Katherine T. Frith and Barbara Müeller (2010, p. 91), the image of a woman in advertising involves the following:

- the stereotyping of a woman into a passive and less powerful player in a society;

- the portrayal of a woman as a sexual object;

- the cumulative effect of these portrayals on woman's self-esteem.

However, the image of a woman being passive and less powerful in the society is disappearing, which is due to the fact that her role in the society is constantly changing. Nowadays, women are very welleducated and successful, they reach very high positions in all areas of life such as business, politics, medicine, education, etc. They look after themselves, wear fashionable clothes and are very demanding. 
The major vehicles for advertising consumer products include commercial television and magazines, particularly those addressing a female audience.

As for the image of men, Benedikt (2005, p. 65) provides a more modern perception of a man in advertising:

- A professionalist. He is well-educated, familiar with the latest global trends, thus willingly shares with his knowledge and acts as an expert. All his movements demonstrate precision, self-confidence and high social status.

- A macho. He is a man who may achieve anything with ease. He is independent, self-confident, surrounded by beautiful women, who are irresistible to him. He is handsome and good-looking.

- A father. He turns up accompanied by housewives, is silent, admires his wife and brilliant children.

\section{History of research on the perception of men in advertising}

Sexual objectification and the portrayal of gender has been the main topic of discussion for many decades. One specific topic has been and continues being discussed how the two sexes have been portrayed in the mass media. However, usually the subject of such research has been women and the feminine gender. The portrayal of men and masculinity has usually been discussed as an afterthought, used to point out the inequalities between men and women, as well as the stereotypical gender associations.

According to Mary Bresnahan et al. (2001), males were more likely to be found outside the home in prime time television commercials, unlike their female counterparts who were more likely to be portrayed indoors, as the mum in her domestic setting. In addition, Bresnahan et al. (2001, p. 124) stated that "only $29.5 \%$ of all role depiction [in U.S. prime time television commercials] were non-stereotypical...[and] that $28 \%$ of American females were depicted in masculine roles". Although the authors state that these findings reflect both the changing status of women and men in U.S. culture, they do not discuss the portrayal of men in traditional feminine roles. This is just one example of various studies that concentrate on the portrayal of women, while neglecting and ignoring the needed examination of the portrayal of men.

However, other observations have been conducted focusing our attention on the portrayal of men. Not only do media images of men make use of stereotypical images of males but also there seems to be an increasing 
number of images of men flaunting their sexuality, especially to promote the beauty products that are traditionally associated with the female market.

According to a study conducted by Leslie McArthur and Beth Resko (1975, p. 218),

\begin{abstract}
Male product users in television commercials were more likely than females to be rewarded with social and career advancement. Female product users, on the other hand, were more likely than males to be rewarded with the approval of family and husband or boyfriend... and were more likely than males to achieve success via [nurturing] relationships.
\end{abstract}

In an analysis of print advertisements from 1958 to 1978, Alice Courtney and Thomas Whipple (1983) concluded that these ads often showed males and females in a stereotypical way, women as sexual objects and men as the decision makers and breadwinners.

Michelle Masse and Karen Rosenblum's (1988) study of the portrayal of men and women in magazine images supports this, finding that females are more likely to be depicted in partial views and/or in a subordinate position (27\% for females versus $4 \%$ for males).

Gerald Skelly and William Lundstrom (1981) observed in their review of advertisements in women's, men's and general interest magazines that "men are increasingly portrayed in decorative roles and less frequently appear in situations involving their manly activities. Only in more recent roles, however, do we see men in non-traditional roles or in which men and women are treated as equals.".

\title{
5. The current study
}

The current study aims to determine:

- How Polish students from the English Departments, who are mainly females, perceive the image of a man in advertising.

Bearing in mind common gender roles division (Washbrook, 2007), the following assumption has been made:

Polish students from the English Department consider the image of men in magazine advertisements in a stereotypical way. In other words, images can be divided into the following categories: a professional, a macho, a father, and a feminised male. 


\subsection{Participants of the study}

$1423^{\text {rd }}, 4^{\text {th }}$ and $5^{\text {th }}$ year students from State University of Applied Sciences in Konin took part in the study. The number of males amounted to 38 and females to 104. They were all Polish citizens between 23 and 25 years old. Additionally, $1491^{\text {st }}$ and $2^{\text {nd }}$ year students from the Institute of Neophilology, Pedagogical University of Cracow took part in the study. The number of males amounted to 44 and the number of women amounted to 105). All students were also of Polish nationality and they were between 20 and 23 years old.

\subsection{The instrument and procedure}

A questionnaire consisting of 22 questions was designed for the purpose of the study. 7 questions were closed-ended and 15 questions were open-ended. The closed-ended questions concerned gender, their education level as well as the preferences connected with the types of advertisements and slogans. In the next part of the questionnaire, the participants were provided with different types of advertisements and they were asked to comment on them. The advertisements had been carefully chosen bearing in mind different images of women presented in the media. The study took place in November and December 2016. The questionnaire was anonymous and it took around 20 minutes to fill in.

\section{Data analysis}

As far as the analysis of the obtained data is concerned, we will predominantly focus on the discussion of the responses the Polish study participants have given to a set of 7 closed-ended questions. The results are presented below in the form of charts illustrating their subsequent discussion.

The initial two questions concerned gender and the year of study students were in. Due to obvious reasons and apparently miscellaneous replies the students provided we will not discuss them here, as they are not relevant to the scheme of our study.

Let us begin the discussion with question 3 , which is presented below:

Question 3:

Which advertisement /s do you prefer (more than one answer is possible)?
a. TV commercials
b. radio commercials
c. Internet advertisements 

d. billboard advertisements
e. magazine / newspaper advertisements
f. other.

Question 3 - results

Types of advertisements

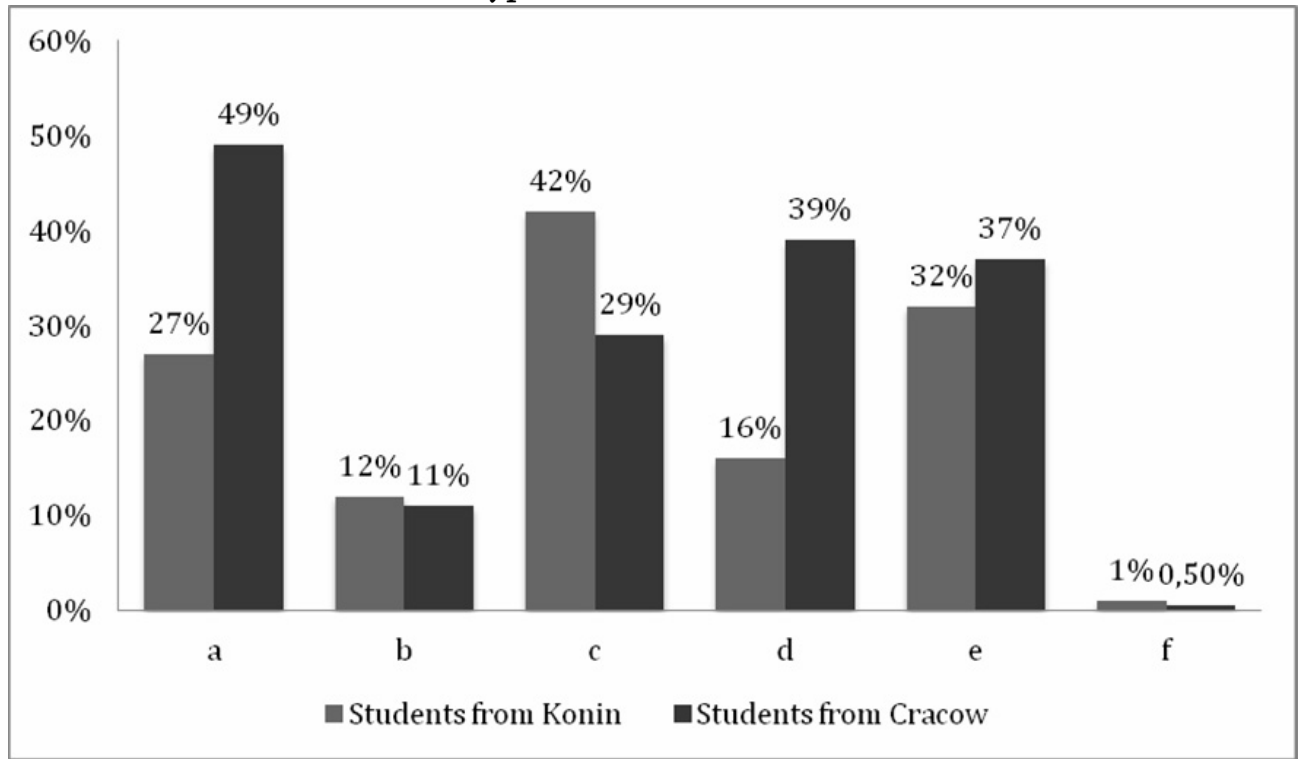

Figure 1. Types of advertisements

As can be seen in Figure 1, respondents from Cracow prefer TV commercials (49\%) and billboard advertisements (39\%) while respondents from Konin prefer Internet advertisements (42\%). Both groups like magazine/newspapers advertisements (32\% and 37\%).

Question 4:

What do you pay attention to when seeing an advertisement / commercial?
a) catchy slogans
b) interesting images
c) humour
d) creative and original ideas
e) famous person
f) other 
Question 4 - results

The most important things when paying attention to advertisements

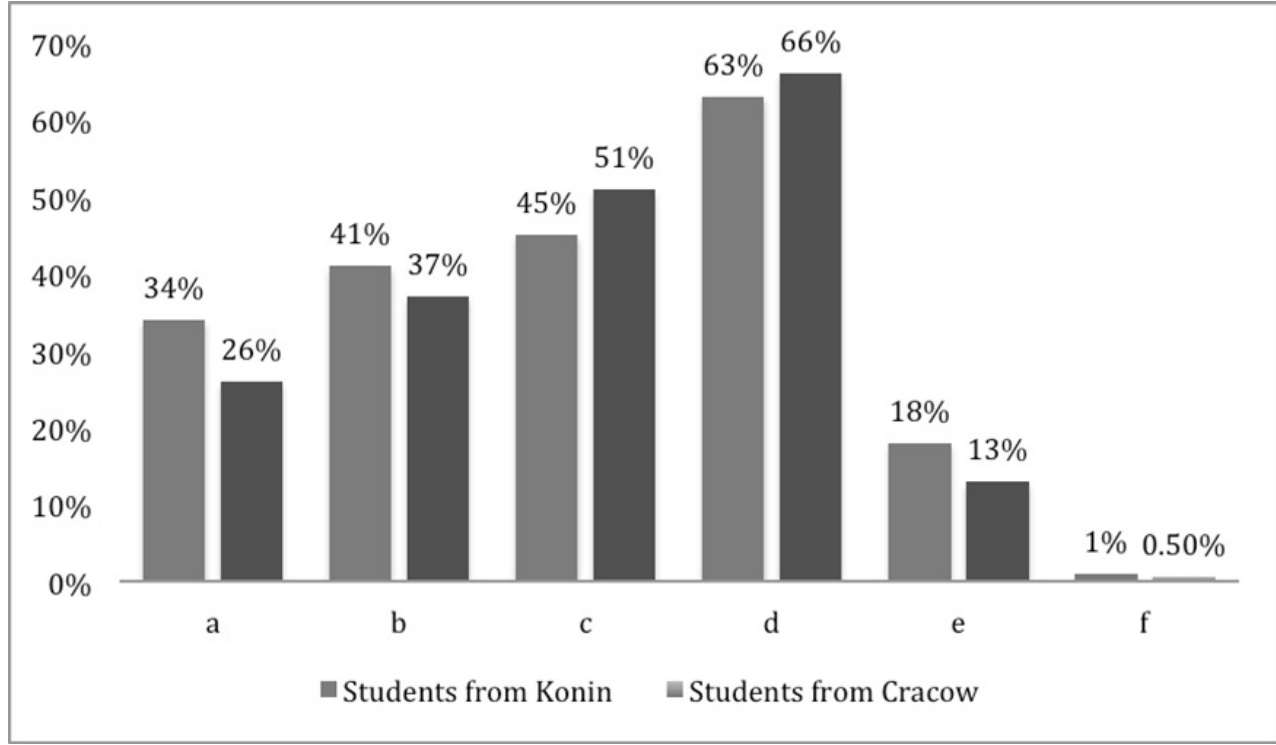

Figure 2. The most important things when paying attention to advertisements

Both groups, namely respondents from Konin and Cracow consider creative and original ideas as the most important when choosing a favourite advertisement (63\% and 66\%). Then they think that humour is extremely important $(45 \%$ and $51 \%)$ and finally interesting images or catchy slogans (41\% and $37 \%$; $34 \%$ and $26 \%)$.

Question 5 - results

\section{Source of information}

5. Do you think that advertisements are a valuable source of information for people?
a) Yes
b) I don't know
c) No 


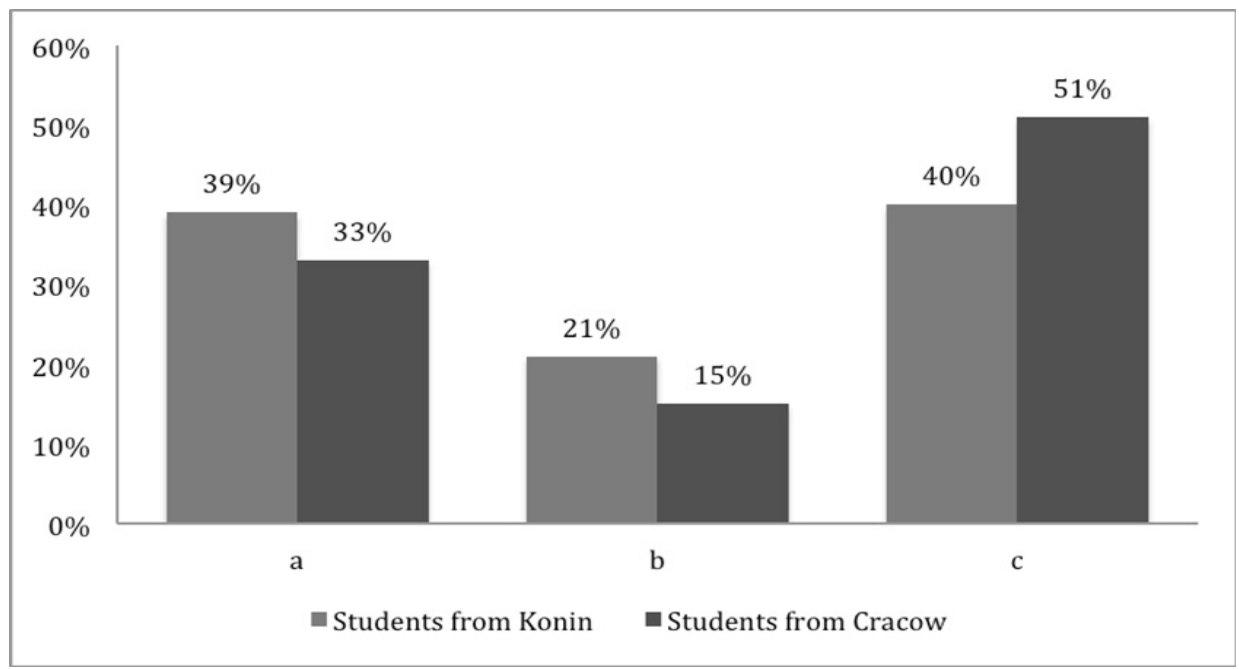

Figure 3. Advertisements as sources of information

Most of the study participants did not agree that advertisements were a valuable source of information for people (40\% and $51 \%$ ). $39 \%$ of students from Konin and 33\% of students from Cracow agreed that advertisements constitute a valuable source of information for potential viewers or listeners. $21 \%$ of students from Konin and 15\% students from Cracow were not certain and could not decide which opinion should prevail in their choices.

\section{Question 6 - results \\ Language of advertising}

6. Do you think that the language of advertising is appropriate?

a) Yes

b) I don't know

c) No 


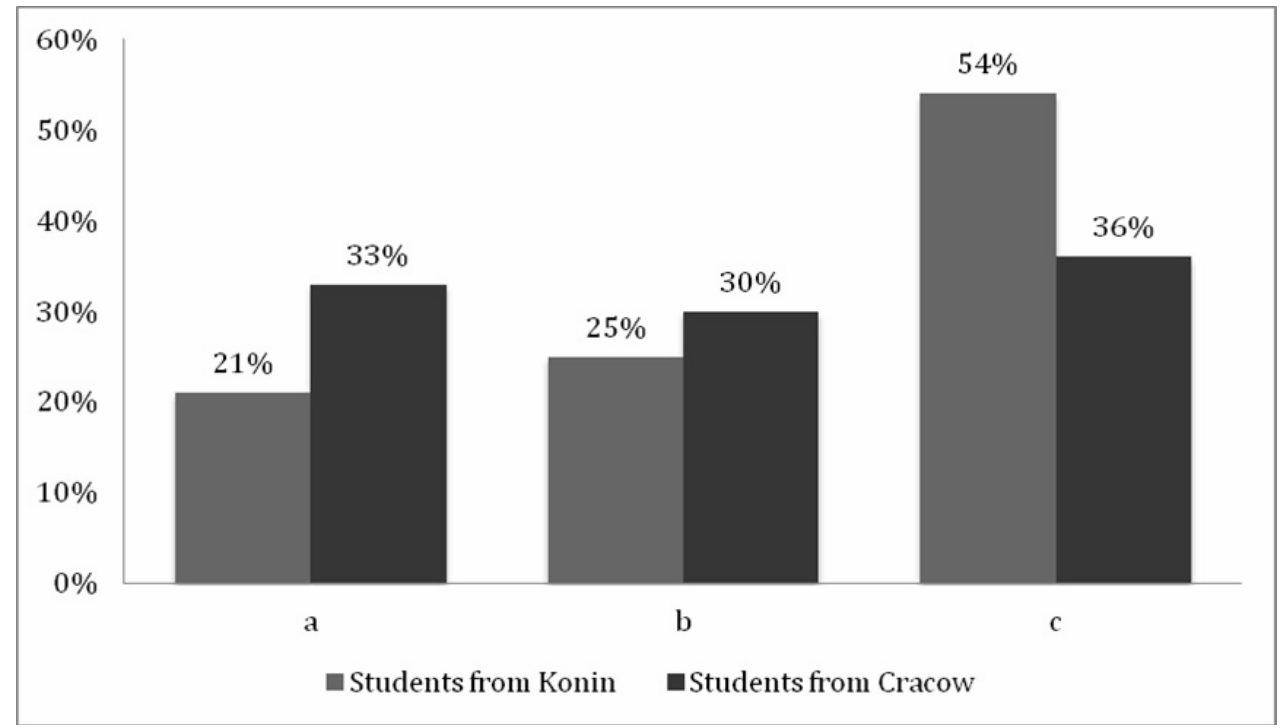

Figure 4. Language of advertising

When looking at Figure 4, it can be seen that $54 \%$ of the respondents from Konin consider language of advertising inappropriate. The percentage is much lower in the case of the respondents from Cracow, namely 36\%. Only $21 \%$ of the respondents from Konin think that the language of advertising is appropriate and $25 \%$ have no idea. In the case of the students from Cracow, the answers are very similar: $33 \%$ think that it is appropriate and $30 \%$ circled the answer "I don't know".

\section{Question 7 - results}

\section{The image of a man in advertising}

7. Do you think that the image of a modern man is well presented in advertising?

a) Yes

b) I don't know

c) $\mathrm{No}$ 


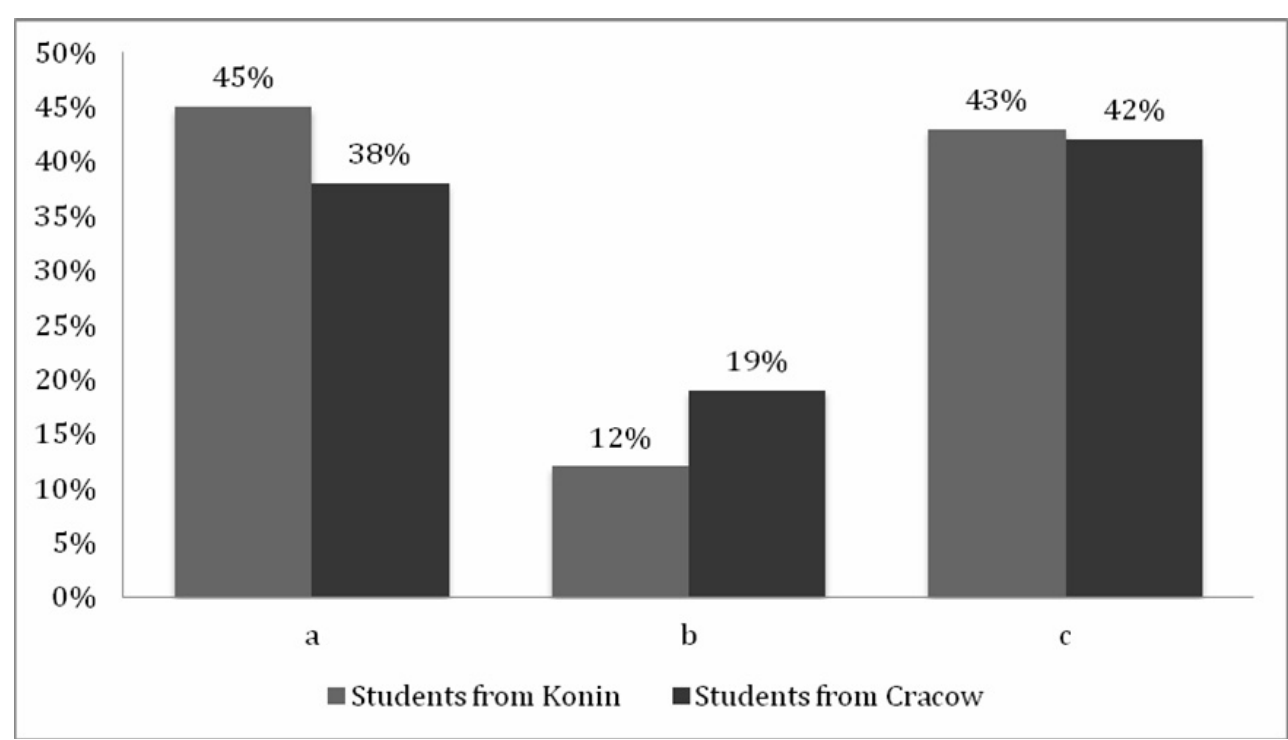

Figure 5. The image of a man in advertising

When looking at the results provided by the respondents it can be seen that the opinions are definitely different. $43 \%$ of the respondents from Konin think that the image of a modern man is well presented in advertising while $45 \%$ of the respondents from Konin have a totally different opinion. The data is very similar in the case of the respondents from Cracow: $42 \%$ think that the image of a modern man is well presented and 38\% do not agree. $12 \%$ of the respondents from Konin and 19\% of the respondents from Cracow had no idea what to answer.

As for this section of our questionnaire, here our students were requested to respond to 3 identical open-ended questions related to 5 advertisements. The instruction and the questions were the following

Open-ended questions:

Please comment on the following advertisements:

- Do you like this advertisement (why/why not?)?

- What is the image of the man presented?

- What do you think about the slogan? 
THE RESULTS OF THE CURRENT STUDY (AD 1)

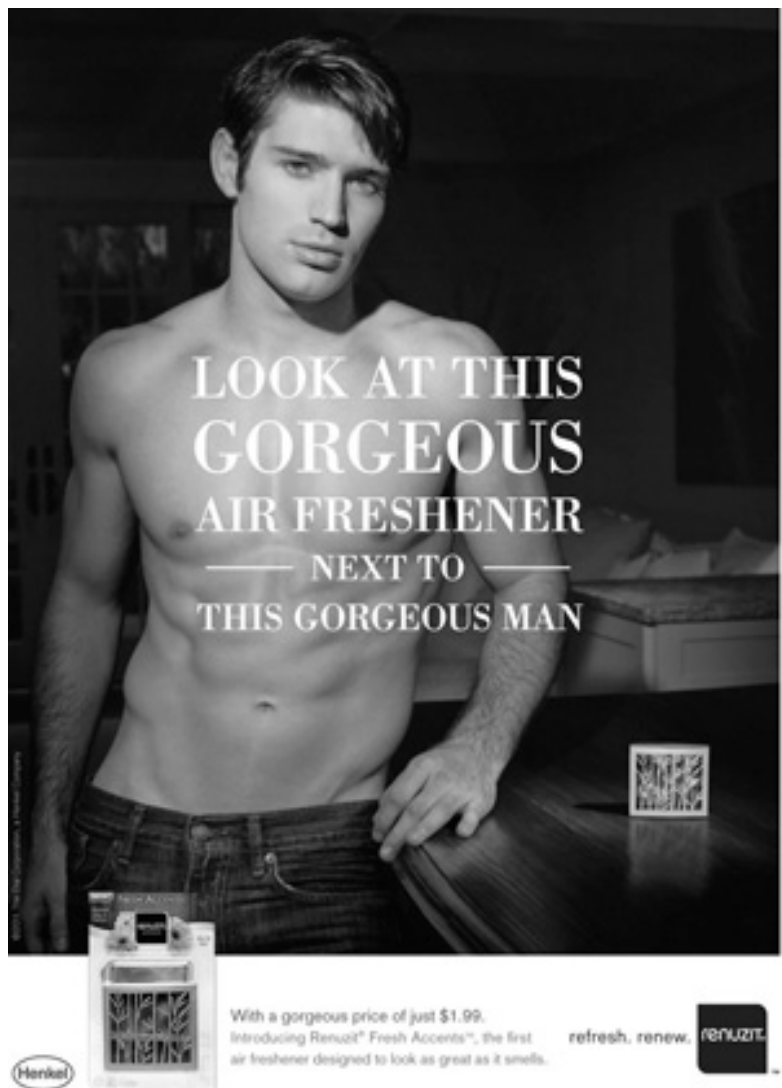

Students' selected answers (Konin):

- (Females) "The man is very attractive. I love the advertisement. The slogan is great - gorgeous man!"

- "It's very interesting. I wish I had such a good-looking husband."

- "Sexy man, fantastic."

- (Males) "The man is supposed to be handsome... well, he is but for me he looks like Ken - Barbie's husband."

- "I like this advertisement. I wish I could look like him. He is definitely gorgeous."

Students' selected answers (IN Krakow):

- (Females) "Yes, I do. It is a funny and clever way of advertising something as boring as a freshener."

- "It presents a good-looking man. $\mathrm{He}$ is fit, even muscular and handsome." 
- " "It is funny and clever. I think it is a hilarious comparison."

- (Males) "I don't like it because it focuses more on a model than on a product itself."

- "He is fit. It seems he takes care of his body, hair, etc."

\section{THE RESULTS OF THE CURRENT STUDY (AD 2)}

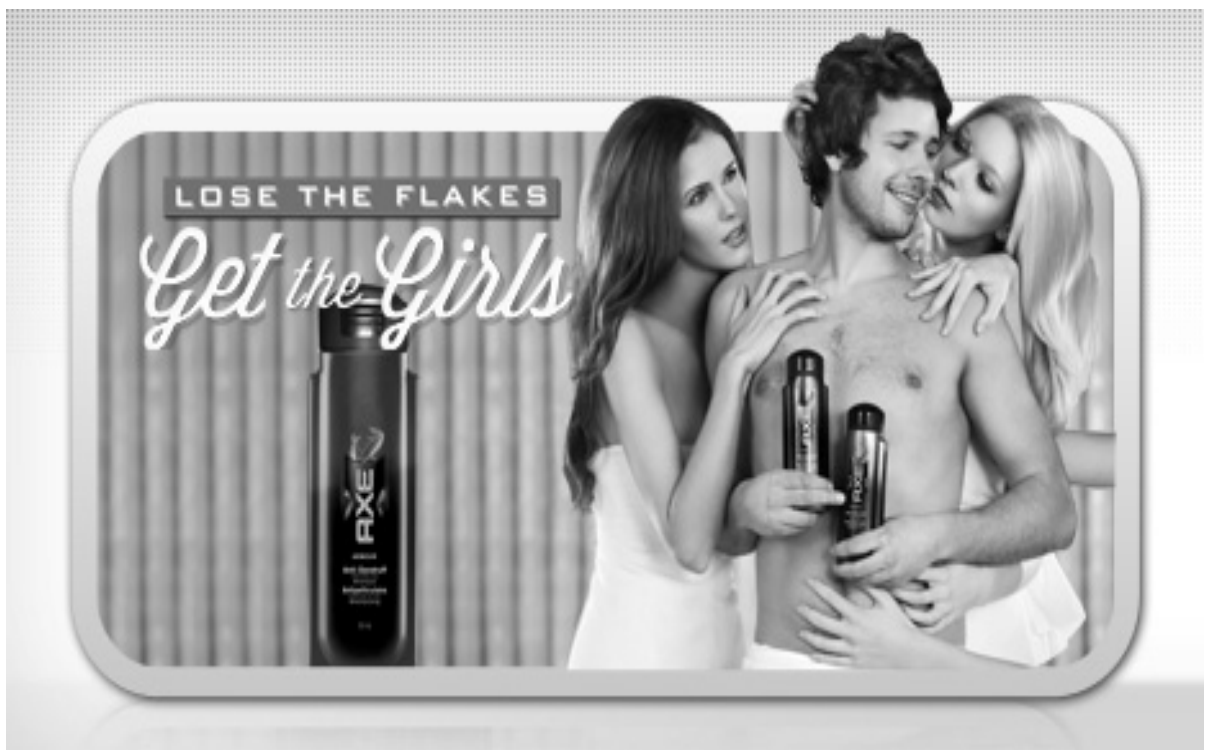

Students' selected answers (Konin):

- (Females) "No, I think it is too direct. The man is presented as having many girls. I don't like the slogan."

- I don't like this advertisement because the man is presented as a selfish person with many girls."

- (Males) "I don't like it. It promotes sexism."

- "It is a bad advertisement. The guy is presented as a womanizer. We are not like that. We don't get girls!"

- "I don't like it. It's an image of a dirty man who needs to wash himself to be attractive."

Students' selected answers (IN Krakow):

- (Females) "I don't like this advertisement. It is also too obvious and presents women not from the best side."

- "He is presented as a playboy, who feels really confident surrounded by women." 
- "The slogan is catchy, and that's the only thing which appeals to me in this advertisement, but not in $100 \%$."

- (Males) "It may be successful when it comes to selling the product, but I don't like it because of the usage of women image."

- "It's a good-looking guy."

- "It's quite catchy and helps to remember the product."

THE RESULTS OF THE CURRENT STUDY (AD 3)

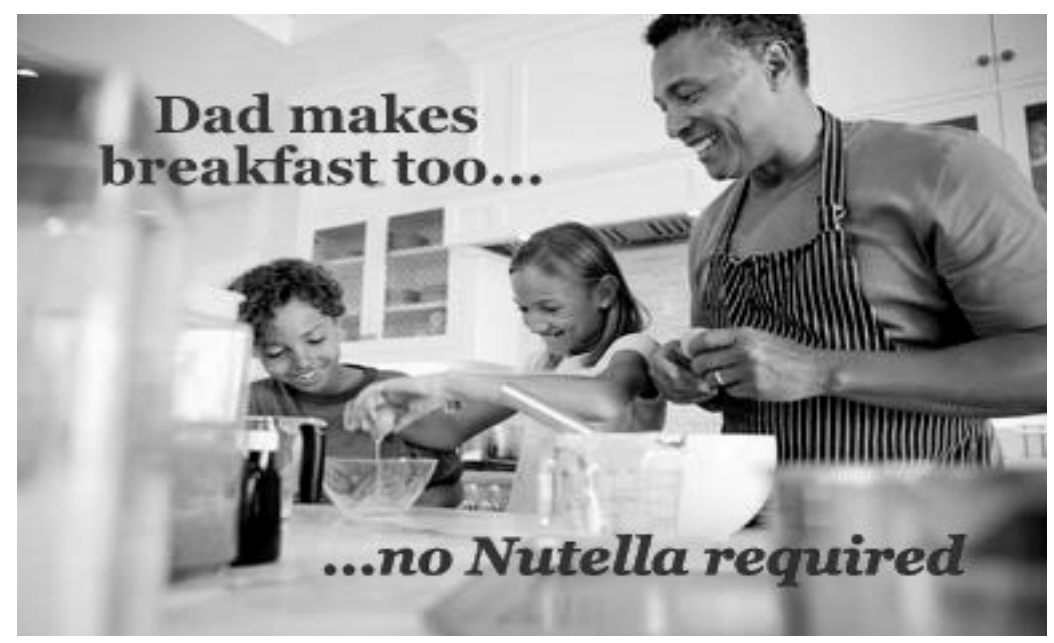

Students' selected answers (UAS Konin):

- (Females) "I like it because it presents a family. The image is very warm. A man is presented as a happy father who likes spending time with his kids."

- "A man is presented as a caring and loving person for whom the family is the most important. He is a responsible person who likes cooking. Very nice slogan."

- "It's a very positive image of a man who is taking care of his children. It's a much better image from the previous ones."

- (Males) "I like this ad because it's catchy and presents an image of a man who is a perfect father looking for kids and preparing food for them."

- "Nothing special. A man preparing food for kids. Men should not prepare food, women should do it" 
Students' selected answers (IN Krakow):

- (Females) "I like it. I think it shows that men and women are equal, that we don't have any gender roles. I hate when people think we still have them."

- "It's good. There's everything OK with it. And what I like the most about it - it's diverse."

- "I like it. It breaks our gender roles, which are very stupid. Men can cook and women can fix a car. We all have to forget about gender roles."

- (Males) "To be honest I don't really understand this ad, so I don't like it."

- "It's a middle-aged man. He's making breakfast for his kids. He seems to enjoy what he is doing."

- "It refers to the fact that not only woman can make meals and it says that men and women are equal."

\section{THE RESULTS OF THE CURRENT STUDY (AD 4)}

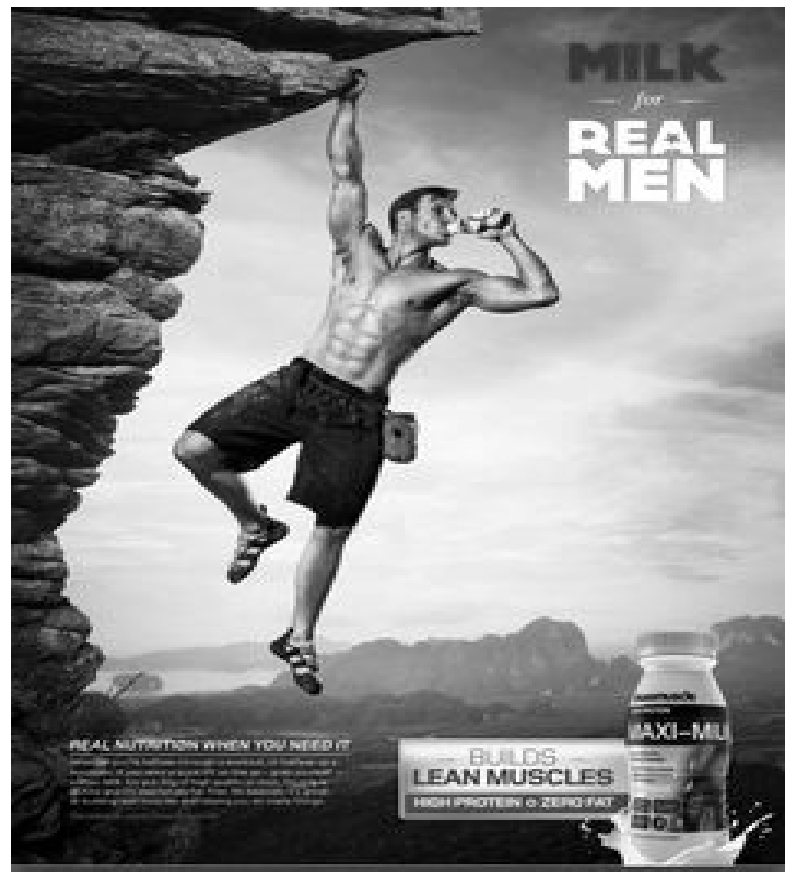

Students' selected answers (UAS Konin):

- $\quad(\underline{\text { Females }})$ "I like it. The man is presented as a strong one. He is fit and sporty."

- "Definitely eye-catching! I love the muscles. This is what a real man should look like. The slogan is very catchy." 
- "No, I don't like it. Strong, thirsty and irresponsible. Drinking in this position isn't safe;-)."

- (Males) "The man seems to be immortal and strong. I like it!"

- "No, I don't like it. It's obvious. All men are strong and sporty."

- "I like it and I like the slogan. Men should be strong and sporty."

Students' selected answers (IN Krakow):

- (Females) "I rather like it. It is creative, and it follows the trends of this generation."

- "A little bit too affected. I'm not keen on the idea just that men who drink the beverage are strong and real. But this image is still rather attractive than sexual."

- "A little bit discriminatory."

- (Males) "Yes. I know about the product, maybe I would buy it. I like knowing about the product. It's addressed to sportsmen."

- "Masculine, strong, other men would like to have a body like him. Good for an advertisement related to sport."

- "Short, easy to understand. Telling about 'real men', promoting a way of how a man should be like. Manipulative, but not in a wrong way because promoting being strong is not bad. Good for sportsmen."

\section{THE RESULTS OF THE CURRENT STUDY (AD 5)}

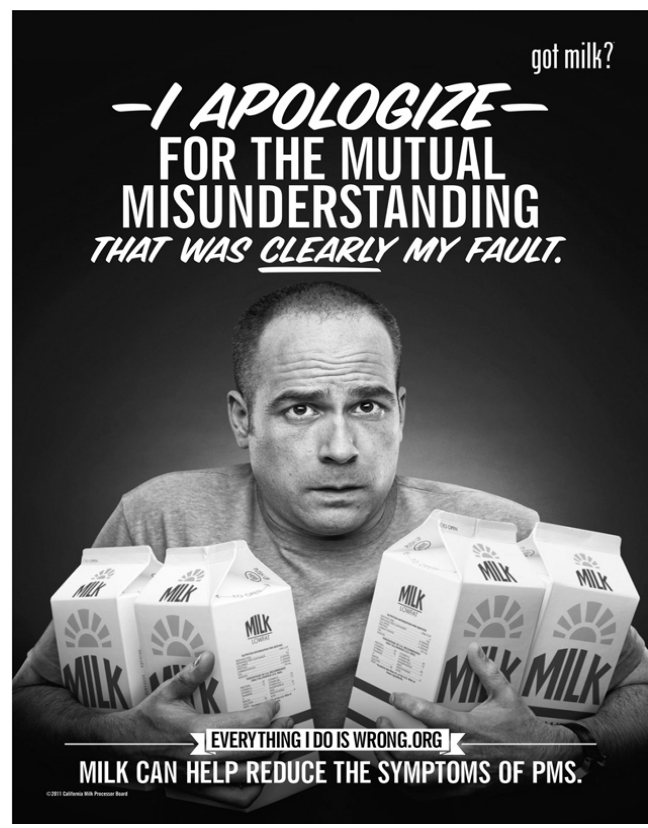


Students' selected answers (UAS Konin):

- (Females) "The man is presented as a poor creature who is afraid of woman. I like it. It's very funny... and true(:)"

- "I like it. Each man should be afraid of a woman and should never argue."

- "It is really witty. I like it. The man is a bit frustrated and the slogan is ironic but funny."

- (Males) "It's really amusing. I have a feeling that it's me. I always need to apologise to my girlfriend."

- "This is the best image of the man. This is what life is like. Men always need to say 'sorry' and they are always the ones to blame for everything."

- "I don't like it. The man is afraid of a woman. We are not afraid of women, they should know that."

Students' selected answers (IN Krakow):

- (Females) "I don't like it. The man in the picture doesn't look good."

- "It's a scared man. Probably he's scared of his wife. Why should I buy that milk from a scared man?"

- "I think it's cheap and that „PMS" thing is too funny to take it seriously."

- (Males) "Something different. It probably shows true and practical information, especially for males who aren't single."

- "It shows a man, who is probably a husband or boyfriend and his woman has PMS. It's funny and not as standard and boring as most contemporary adverts."

- "It's good. It's funny and presents practical info."

\section{Discussion}

Bearing in mind the results obtained from the afore-mentioned questionnaire we will proceed to the discussion of the results.

In question 3, the students were asked to respond and list the most frequently favoured type of advertisements. Most students from the Pedagogical University of Cracow prefer TV commercials and billboard advertisements while the students from the State University of Applied Sciences in Konin prefer Internet advertisements. Both groups of the respondents indicated magazine/newspaper advertisements as the ones which they liked. At this stage it can be concluded that TV commercials, Internet 
advertisements tend to prevail over the remaining types of advertisements, which is probably due to their availability. Most students have a TV set or a computer with the Internet access which allow them to watch these types of advertisements.

In question 4 , the students were requested to indicate what they pay attention to when seeing an advertisement/commercial. Both groups, namely the respondents from the Pedagogical University of Cracow and the respondents from the State University of Applied Sciences in Konin selected creative and original ideas as the most important. Then both groups indicated humour and finally interesting images and catchy slogans. Creative and original ideas are definitely the most important factors for young people when choosing favourite advertisements. Nowadays, there is a trend to create advertisements that are shocking, funny and original. People, especially the young ones, tend to get bored when seeing monotonous and repetitive advertisements. Original advertisements make people remember the products advertised and often have an impact on the choice of the products (Svetlana Frolova, 2014).

In question 5 , the students were requested to share their opinions on the question whether advertisements were a valuable source of information. The opinions differed. Around half of the respondents did not agree that advertisements were a valuable source of information and around $40 \%$ of them stated that they were a valuable source of information. The rest could not decide which answer to choose. The results indicate that young people differ in their opinions, which can be interpreted as a very good sign. It is very good that they do not have the same opinions and are very willing to express them.

The focus of question 6 was on the language of advertising. The respondents were asked to indicate if the language was appropriate or not. More than $50 \%$ of the respondents from the State University of Applied Sciences consider language of advertising inappropriate. The percentage is much lower in the case of the students from the Pedagogical University of Cracow, only around $30 \%$. Only around $20 \%$ of the respondents from Konin and around $30 \%$ of the respondents from Cracow consider the language of advertising appropriate. The other respondents circled the answer "I don't know". One comment that comes to our mind when analysing the data obtained is that students from Konin tend to be more sensitive to the language of advertising due to the fact that they come from a much smaller place. Konin is a small city and most of the students come from the villages around Konin therefore their perception of appropriateness is different. The students from 
Cracow tend to be more tolerant. They live in a big city, have access to more facilities, meet people from various countries and therefore become more openminded.

The final question in this part of the questionnaire focused on getting to know the students' opinions with reference to the image of men presented in advertising. Around $40 \%$ of the respondents from the State University of Applied Sciences in Konin and from the Pedagogical University of Cracow think that the image of a man in advertising is not well presented. Nearly the same percentage of the respondents from both institutions think that it is well presented. The rest of the respondents circled the answer "I don't know". The data gathered from this question is very surprising. On the one hand, the respondents think that the image of a man is well presented and on the other hand, they state something completely opposite. The only conclusion that comes into our mind goes in tandem with the conclusion presented above namely: the young people tend to have different opinions, which indicates that their perception of men in advertising is diverse.

In the remaining part of the questionnaire, the respondents were asked to express their opinions after having seen the selected advertisements supplemented by slogans. Due to insufficient space, we have decided to select the most repetitive and frequent responses provided by the students.

In the light of the research conducted by Frith and Müller (2010), the comments provided by students after they have seen Advertisement 1 and 2 are that most female students perceive men presented in these advertisements as sexual objects (e.g. "The man is very attractive. I love the advertisement. The slogan is great - gorgeous man!"). Males tend to have different opinions; they find these men a bit funny - "Ken or Barbie like". Following Frith and Müller's (2010) comments on the perception of advertisements, we agree that nowadays, there is a tendency to present both men and women as sexual objects because this is what attracts people.

In Advertisement 3, a man is presented as a warm father who spends time with his children. Most of the comments provided by the students were very positive, especially the ones provided by females (e.g. "A man is presented as a caring and loving person for whom the family is the most important. He is a responsible person who likes cooking. A very nice slogan"). Males tended to be quite sceptical. For some of them there was nothing special about the man spending time with his kids (e.g. "Nothing special. A man preparing food for kids. Men should not prepare food, women should do it"). The perception of a man is very common nowadays. Benedict (2005) considers it to be one of the most important and welcome perceptions of a man, which has changed 
within the last decade, and the above comments provided by the respondents prove that such role of a man is very much appreciated, especially by females.

In Advertisement 4, a man is presented as a strong, sporty and full of energy person. Nearly all respondents both males and females liked this image of the man (e.g. "I like it. The man is presented as a strong one. He is fit and sporty" or "The man seems to be immortal and strong. I like it!"). Benedict (2005), among his categories, provides the one that refers to the descriptions provided by the respondents (a macho). It might seem that this perception of a man is old-fashioned but in fact, it is evident, as most males have always wanted to be strong and fit and what is more they have always wanted to be perceived like in this way by women. The last image of a man presented in Advertisement 5 is very humorous, especially if one pays attention to the slogan "I apologise for the mutual misunderstanding. That was clearly my fault". A man is presented as a person who is afraid of women. This image of a man is often presented in some jokes, as well and if we analyse the comments provided by the respondents it can be noticed that they like these kinds of advertisements and consider them very clever. Irrespective of whether it is true or not it is definitely very humorous. The last but not least are the slogans presented in the advertisements. All of them seem to "elicit emotions" (Messaris, 1997: 7) e.g. "I like this advertisement. I wish I could look like him. He is definitely gorgeous" (Ad 1) - here the respondent even used the same words from the slogan. What is more, they also "serve as photographic proof that something really happened" (ibidem) e.g. "It refers to the fact that not only woman can make meals and it says that men and women are equal" (Ad 3) - a very clear reference to the image presented in the advertisement. Finally, "they can establish an implicit link between the thing that is being sold and some other images" (ibidem) e.g. "The man is presented as a poor creature who is afraid of woman. I like it. It's very funny... and true(:)". The slogan directly refers to the situations, which are often shown on TV, discussed on the radio or presented in some cabarets. From the linguistic point of view, all the slogans are short, contain familiar and only necessary words to communicate the message, are written in active voice and present tenses (Benedict, 2005), therefore, they quickly reach the audience.

\section{Conclusions and future implications}

To sum up, Polish students from the English Departments regard the image of a man in magazine advertisements as stereotypical. 
On the basis of the research the following perceptions of a man can be enumerated:

- Man as a sexy, handsome and strong person desired by women (macho);

- Man as a caring, loving and responsible person for whom family is the most important;

- Man as a professional, sporty and strong person looking after his health and body;

- Man as a person who is afraid of women and always willing to search for a compromise;

What is more,

- Females tend to have a positive attitude to the men presented in advertising - they liked all images;

- Males tend to have a negative attitude to the men presented in advertising - they did not like men being presented as womanizers, sexy objects or poor guys afraid of women.

FUTURE IMPLICATIONS:

- Subsequent studies with more open-ended questions and a higher number of gender-related advertisements should be conducted.

- The perception of a woman and a man in advertisements should be compared.

Such studies would allow us to collect more detailed results.

\section{REFERENCES}

Benedikt, A. (2005). Reklama jako proces komunikacji. Wrocław: Wydawnictwo Astrum.

Bresnahan, M. J., Inoue, Y., Liu, W. Y., \& Nishida, T. (2001). Changing gender roles in primetime commercials in Malaysia, Japan, Taiwan, and the United States. Sex Roles: A Journal of Research, 45(1-2), 117-131. https://doi.org/10.1023/A:1013068519583

Caples, J., \& Hahn, F. (2000). Skuteczna reklama. Warszawa: Dom Wydawniczy ABC.

Courtney, A. E., \& Whipple, T. W. (1983). Sex stereotyping in advertising. Lexingtion, MA: Lexington Books.

Crawford Camiciottoli, B. (2010). Discourse connectives in genres of financial disclosure: Earnings presentations vs. earnings releases. Journal of Pragmatics, 42/3, 650-663. https://doi.org/10.1016/j.pragma.2009.07.007

Crystal, D. (2001). Language and the Internet. Cambridge: Cambridge University Press. https://doi.org/10.1017/CBO9781139164771

Danciu, V. (2014). Manipulative marketing: persuasion and manipulation of the Consumer through advertising. Theoretical and Applied Economics, XX1, 2(591), 19-34.

Frith, K. T., \& Müeller, B. (2010). Advertising and Societies. Global Issues. New York: Peter Lang Publishing. 
Frolova, S. (2014). The Role of Advertising in Promoting a Product. [Unpublished doctoral dissertation]. Centria University of Applied Sciences.

Furnham, A. \& Mak, T. (1999). Sex- role stereotyping in Television Commercials: A Review and Comparison of Fourteen Studies Done on Five Continents Over 25 Years. Sex Roles, 41, 413-437. https://doi.org/10.1023/A:1018826900972

Furnham, A., \& Paltzer, S. (2010). The Portrayal of Men and Women in Television Advertisements: An Updated Review of 30 Studies Published Since 2000. Scandinavian Journal of Psychology, 51, 216-236. http://dx.doi.org/10.1111/j.1467-9450.2009.00772.x

Kay, A., \& Furnham, A. (2013). Age and sex stereotypes in British Television Advertising. Psychology of Popular Media Culture, 2, 171-186. http://dx.doi.org/10.1037/a0033083

Keller, K. L. (1993). Conceptualizing, Measuring, and Managing Customer-Based Brand Equity. Journal of Marketing Research, 29, 1-22. https://doi.org/10.2307/1252054

Knoll, S., Eisend, M., \& Steinhagen, J. (2011). Gender roles in advertising: Measuring and comparing gender stereotyping on public and private TV channels in Germany. International Journal of Advertising, 30(5), 867-888. https://doi.org/10.2501/IJA-30-5867-888

Masse, M, A., \& Rosenblum, K. (1988). Male and female created they them: The depiction of gender in the advertising of traditional women's and men's magazines. Women's Studies International Forum, 11(2), 127-144. https://doi.org/10.1016/0277-5395(88)90044-1

McArthur, L., \& Resko, B. (1975). The portrayal of men and women in American television commercials. Journal of Social Psychology, 97, 209-220. https:/doi.org/10.1080/ 00224545.1975.9923340

Messaris, P. (1997). Visual Persuasion: The Role of Image in Advertising. California: Sage Publications.

Shaw, P., Eisend, M., \& Tan, Y. (2014). Gender-Role Advertising in International Advertising. In H. Cheng (Ed.), The Handbook of International Advertising Research (pp. 299-312). Hoboken, NJ: Wiley-Blackwell. https://doi.org/10.1002/9781118378465.ch15

Skelly, G. U., \& Lundstrom, W. J. (1981). Male sex roles in magazine advertising, 1959-1979. Journal of Communication 31(4), 52-57. https://doi.org/10.1111/j.1460-2466.1981.tb00450.x

Verhellen, Y., Dens, N., \& de Pelsmacker, P. (2016). A longitudinal content analysis of gender role portrayal in Belgian television advertising. Journal of Marketing Communications, 22(2), 170-188. https://doi.org/10.1080/13527266.2013.871321

Yule, G. (2005). Words and word-formation processes. In The Study of Language (pp. 52-61). Cambridge: Cambridge University Press. doi:10.1017/CBO9780511819742.007

\section{Online sources}

http://www.medialit.org/reading-room/images-men-advertising

https://www.psychologytoday.com/blog/sideways-view/201604/are-men-and-women-portrayeddifferently-in-tv-ads 
